\title{
The Impact of Relative Exchange Rate Volatility and Other Multidimensional Determinants on FDI in Egypt
}

\author{
Abd-El Atti Nadine*, Salah Ashraf, Rashid Nagia \\ Department of Finance, College of Management and Technology, Arab Academy for Science and Technology, Alexandria, Egypt \\ Email: *Nadine.a.abdelatti@aast.edu
}

How to cite this paper: Nadine, A.-E. A., Ashraf, S., \& Nagia, R. (2021). The Impact of Relative Exchange Rate Volatility and Other Multidimensional Determinants on FDI in Egypt. American Journal of Industrial and Business Management, 11, 1163-1197. https://doi.org/10.4236/ajibm.2021.1112071

Received: November 3, 2021

Accepted: December 7, 2021

Published: December 10, 2021

Copyright $\odot 2021$ by author(s) and Scientific Research Publishing Inc. This work is licensed under the Creative Commons Attribution International License (CC BY 4.0).

http://creativecommons.org/licenses/by/4.0/

\begin{abstract}
The current trends of financial globalization have provided worldwide investors a great opportunity to invest and increase the financial flows between developed and developing countries through foreign direct investment. Foreign direct investment (FDI) has been viewed by developing countries as a crucial source of economic development and rapid economic growth by transferring advanced technology and management expertise from developed countries to developing countries. After the collapse of Bretton Woods Agreement, the majority of the countries adopted flexible/floating exchange rate systems. Thereafter, uncertainty arose in several countries as a result of the large fluctuations in currency prices. Consequently, exchange rate volatility (ERV) has gained attention from researchers, due to its perceived importance and many studies have investigated the impact of exchange rate volatility on FDI; however, there have been long debates and controversies regarding the impact of ERV on FDI. Researchers have argued that to reach better comprehensive results, some determinants that impact FDI have been studied along with ERV. This study employs the basic FDI gravity model as well as the augmented FDI gravity model using the data collected for forty-two source countries over the period 2005-2019. While using a Generalized Method of Moments (GMM) estimation approach, this research intends to provide better understanding of the impact of relative ERV on inward FDI to Egypt as well as investigating the impact of other relative dimensions on inward FDI to Egypt from these source countries. Results have revealed that relative exchange rate volatility has a negative impact on inward FDI to Egypt. It has also been conducted that market size of home countries and host country exert a significant positive impact on inward FDI to Egypt. Geographic distance, bilateral trade, relative cost of borrowing, relative labor productivity, and relative corruption are found to be statistically significant for inward FDI to Egypt.
\end{abstract}




\section{Keywords}

Exchange Rate Volatility, Foreign Direct Investment, Augmented Gravity Model, GMM Estimation Approach, Dynamic Panel Data Model

\section{Introduction}

In recent years, there has been a dramatic increase in both the observed amounts of foreign direct investment (FDI) flows and the academic literature attempting to explain these flows in the context of both host and source countries. FDI flows are considered among the most important and significant investment decisions, as firms located in source countries choose where they are willing to invest their funds and that many determinants affect their decision which can encourage or discourage them to invest in a particular host country. Hence, foreign direct investment has been attracting the attention of many researchers for a long time, and it has increasingly become a topic of discussion and the subject of investigation in a number of countries. According to $\operatorname{UNCTAD}(2006,2020)$, the global FDI flows in 2005 reached $\$ 916$ billion, and increased throughout the years to reach $\$ 1.53$ trillion in 2019 which shows the increasing and growing attention for FDI flows among countries, and how countries are deploying efforts to provide incentives for foreign investors to increase FDI flows.

After the collapse of Bretton Woods Agreement, the world witnessed a change in their currency and most of the countries adopted a flexible exchange rate regime, which resulted in fluctuations in exchange rate. These fluctuations raised the uncertainty and the risk faced by foreign investors. Therefore, exchange rate volatility began to gain the attention of many researchers, and they started to examine the impact of exchange rate volatility on FDI. Not only this, researchers did not reach a clear understanding about the impact of ERV on FDI, and examined more variables along with the ERV to get a comprehensive logic of what attracts more inward FDI to a country.

The impact of exchange rate volatility on inward FDI is controversial as empirical studies have generated contradicting results as well as theories. Therefore, there are many country specific determinants that can impact inward FDI other than relative exchange rate volatility. Consequently, this situation has pushed researchers to conduct further studies in order to identify the determinants which attract more inward FDI to the host country. Also, by reviewing the academic literature, it is found that various studies have investigated the effect of FDI determinants on total FDI inflows to host country while only a few studies have tackled the issue of relative FDI determinants between the source and host country and how it affects inward FDI to host country such as the studies conducted by [Grosse and Trevino (1996); Thomas and Grosse (2001); Kimino et al. (2007); Dauti (2015); Jena \& Mishra (2018)]. However, no full consensus has been reached regarding these determinants as it differs from country to another. 
Accordingly, the overall aim of this research is to advance an understanding about the impact of relative real ERV between home and host country on inward FDI as well as the impact of multidimensional determinants on FDI inflows to Egypt from 42 source countries. As previous empirical studies have focused mainly on developed economies as source countries of FDI and developing countries as host countries, this research examines inward FDI from both developed and developing countries which is currently lacking in the literature.

The rest of the paper is organized as follows: the next section presents a literature review providing the theoretical framework and the previous studies of exchange rate volatility, other multidimensional determinants, and FDI. Section three explains the collected data and the methodology employed. In the fourth section, the empirical findings are addressed and analyzed. The conclusion section summarizes the major findings and emphasizes the recommendations and limitations of this study.

\section{Literature Review}

\subsection{Theoretical Framework}

This section presents an overview for foreign direct investment (FDI) and its importance for the host as well as the source country. Afterwards, a theoretical base of some of FDI theories is presented which depicts firstly the impact of exchange rate volatility, and secondly reviews and discusses some of the theories relevant to the impact of some determinants on inward FDI.

\subsubsection{Foreign Direct Investment Overview}

Foreign direct investment is defined by the International monetary fund's Balance of Payments Manual $4^{\text {th }}$ edition, 1977 as

"an investment that is made to acquire a lasting interest in an enterprise operating in an economy other than that of the investor, the investor's purpose being to have an effective voice in the management of the enterprise".

In other words, foreign direct investment is a kind of investment that refers to a movement of capital from the home country which is the investor country to the host country "The recipient" to gain continual benefit. Furthermore, there is a double coincidence of wants for the home and host country which is beneficial for both developed and developing countries as developing countries are facing shortage of capital, and investors from developed countries are seeking high profits as the marginal productivity of capital in developing countries is high. Thus, FDI is essential for economic development of both host and home countries.

The types of FDI can be classified from the source country's perspective which is the investor. Caves (1971) distinguishes between three types of FDI as follows: horizontal FDI, vertical FDI, and conglomerate FDI. The horizontal FDI is an investment with a purpose of horizontal expansion in order to manufacture or make the same or similar type of goods in a foreign country as in the country of origin. The second is vertical FDI which is categorized into two types. The first 
type of vertical FDI is an investment made by the country of origin with a purpose of exploiting raw materials which are called "Backward vertical FDI", and the second type of vertical FDI is an investment made by the country of origin with a purpose of being near the customers through acquisition of distribution outlets which is called "Forward vertical FDI". The third type of FDI is the conglomerate FDI which involves both horizontal and vertical FDI.

\subsubsection{Exchange Rate Overview}

The collapse of Bretton Woods system in 1971 brought major changes and wide variety of choices for exchange rate regimes for countries. According to Aziz \& Caramazza (1998), many developing countries have chosen more flexible regimes since late 1970. However, not only did moving to flexible/floating exchange rate system happen in developing countries, but it affected the majority of the countries which means that the market determines the exchange rate through demand and supply mechanism. Following flexible exchange rate regime helps the country to adjust to external shocks, and government does not need to hold large reserves of foreign currency; thus, the accessibility of financial markets instruments is important in order to hedge the risks related to exchange rate fluctuation.

\subsubsection{Theories of Exchange Rate Volatility and FDI}

\section{1) Production Flexibility Approach}

The production flexibility approach, the so called the real options approach, is adopted by Abel (1983), Cushman (1985, 1988), Goldberg and Kolstad (1995), and it links between exchange rate volatility and foreign direct investment.

This approach asserts that exchange rate volatility increases FDI. There are two main assumptions that explain the production flexibility argument. The basic and first assumption is that producers have the flexibility to adjust the cost of their factors of production such as capital cost, labor cost and price variability. The second assumption concentrates on searching for lower cost plant which creates a diversification for production location.

This approach is studied and used by Aizenman (1992), Darby et al. (1999), and Sung \& Lapan (2000); they examined this approach and developed models that focus on the long-run production flexibility. Another study in Nigeria by Osinubi and Amaghionyeodiwe (2009) supports the evidence for the production flexibility theory.

The production flexibility argument would not hold if factors were fixed. First, multinational companies observe the exchange rates, as under this approach, companies can adjust their variable factors of production when they find out that exchange rate is volatile in a foreign country. Also, they have the potential to increase their capacity; hence, they decide to shift their production to a foreign country. The variability of prices makes it difficult to achieve the desired profits under a production structure with fixed factors; that is why the production flexibility approach relies mainly on adjusting factors of production in order 
to reach the desirable profit.

\section{2) Hysteresis Approach}

The Hysteresis theory is an alternative approach that links the exchange rate volatility and investment, also it can be called the "risk aversion theory" adopted by Dixit and Pindyck (1994) and also Bénassy-Quéré et al. (2001).

This theory hypothesizes that exchange rate volatility decreases FDI inflows, this inverse relationship is caused mainly by the sunk cost, accordingly, firms choose to avoid the risk and they choose to postpone or delay their investments when facing this high volatility of exchange rate because, simply, they will not guarantee the expected return.

Goldberg and Kolstad (1995) pointed out that when taking into account the effect of the variability of exchange rate, making a clear distinction between short term exchange rate volatility and long term misalignments of exchange rates is essential. For long term exchange rate variability, the production flexibility gives a more convincing explanation for the relationship between ERV and foreign direct investment flows. Wherefore, under short-term exchange rate volatility, risk aversion argument gives a more convincing explanation as factors of production are normally fixed, thus, companies will not be able to change production factors in the short run.

Another study by Jeanneret (2007) supported the "Risk aversion theory" and explained that investment costs are irrevocable, and that the anticipation of any new information that could be known and the uncertainty of the real exchange rate create sensitivity of investing decisions. Furthermore, Asmah and Andoh (2013) gave an explanation that when there is a high variability of exchange rate, the returns expected of the investment projects decrease, accordingly FDI decreases.

\subsubsection{The Eclectic Theory}

The eclectic theory is developed by Dunning (1977, 1979, 1988). This theory serves to demonstrate why firms engage in FDI, mainly for the following three factors: ownership advantages $(\mathrm{O})$, location features $(\mathrm{L})$ and internationalization opportunities (I).

The ownership advantages can enable a firm to have control over its tangible and intangible assets while the location features (L) may come up when there are differences between country-of-origin and host county. Such differences could be a lower operating cost, differences in political and cultural environment, better legal system, and better market structure. Therefore, Dunning (1980) confirms that a firm will decide to invest in a foreign market only if it is more appealing than the home market. Finally, the internalization opportunities (I) permit a firm to start foreign production and trade through subsidiaries instead of licensing it.

Subsequently, Dunning (1993) depicts three primary types of FDI from investing firms' perspective: firstly, market-seeking FDI, also termed horizontal FDI where the purpose of the firm located in the source country is to have access 
and serve local and worldwide markets; secondly, resource-seeking FDI, also named vertical FDI or export-oriented FDI, where the purpose of the firms is to invest in a foreign country to get resources such as labor, raw materials, and natural resources like oil, gas. Thirdly, efficiency-seeking FDI, where a firm arranges its operations for economies of scale and controls the geographically dispersed activities through common governance.

\subsection{Previous Studies}

\subsubsection{Foreign Direct Investment by Country-of-Origin}

There are many attempts in order to demonstrate inward FDI flows to host countries; these attempts explain inward FDI from both a micro and a macro perspective. The macro perspective concentrates on country level in order to give an explanation of FDI inflows. Examining FDI from both perspectives is relevant as they complement each other and advance our comprehension of FDI.

Arpan et al. (1981) discovered in the literature review of FDI that till 1981, there was no macro model to demonstrate FDI inflows and/or outflows in a comprehensive way. Researchers such as Root \& Ahmed (1979) and Culem (1988) started to examine FDI inflows/outflows using macro approach. Even though there are many studies examining foreign direct investment from a macroeconomic view, most of these studies have failed to incorporate the related variables into a complete and explicative model of FDI.

Ajami \& Barniv (1984), Tallman (1988), and Grosse \& Trevino (1996) turned their attention to study FDI from a different perspective by using country-oforigin FDI determinants and its impact on host countries FDI. All of these scholars, who attempted to offer a clear explanation of FDI by country-of-origin, have worked on the US as a host country.

Thereafter, studies examined the impact of some determinants on FDI employing the gravity model. This model is based on the gravity equation in physics, hence the inspiration of this model emanated from Newton. The gravity model was first introduced for the analysis of international trade flows by Tinbergen in 1962 and Pöyhönen in 1963, and then Eaton \& Tamura (1994) and Bevan \& Estrin (2004) applied the gravity model for FDI flows. Head and Mayer (2014), in their study, stated that the simplicity of this model as well as the possibility of comparing this model to various theoretical frameworks are the main advantages. Several studies used the gravity model such as the studies conducted by [Roberts \& Almahmood (2009); Ismail (2009); Dauti (2015); Kahouli \& Maktouf (2015); Barrell et al. (2017); Hanh (2020)]. These studies did not focus only on the main determinants of the basic gravity model which are as follows: market size of home country, market size of host country, and the geographic distance between both home and host countries, but also added other determinants of FDI in the gravity model which are called the augmented gravity model. 


\subsubsection{Determinants of Foreign Direct Investment}

\section{1) Exchange Rate}

The study carried out by Froot \& Stein (1991) demonstrates FDI movement to United States covering the period from 1973 to 1990, and it revealed that the depreciation in the currency of the host country increases FDI inflows. They discussed that the appreciation of the country-of-origin's currency relative to that of the host country' improves the wealth position of the companies located in home country, and decreases the relative cost of capital by letting them invest more aggressively in host country and purchase their assets as well; thus, drove to a higher FDI inward in the host country.

This argument is congruent with the work of the following researchers in their studies [Bénassy-Quéré et al. (2001); Ajami and Barniv (1984); Cushman (1985); Grosse and Trevino (1996)] which signify that an appreciation of the home country's currency must be related to a higher outward FDI from the firms in the home country to the host country.

Additionally, Jena \& Mishra (2018) included the real exchange rate of the host country in their augmented gravity model. The findings indicate a significant inverse relationship between real exchange rate and FDI. Furthermore, Hanh (2020) demonstrated the effect of bilateral exchange rate on China's FDI inflows. The findings indicate the presence of a negative and significant coefficient implying that a depreciation of the host country's currency attracts further FDI to China and Vietnam.

Conversely, Lemi \& Asefa (2001); De Vita and Abbott (2008); Kenneth et al. (2017) studied the impact of exchange rate on the inflow of FDI. Results of these studies revealed that exchange rate is statistically insignificant.

\section{2) Exchange Rate Volatility}

Over the years, an enormous amount of research has been conducted to determine the impact of exchange rate volatility on FDI with some showing positive correlation between exchange rate volatility and FDI whereas other studies show a negative one. There is no clear consensus that exists in the literature over whether there is a positive, negative or no relationship between ERV on FDI.

A study by Cushman (1985) found a positive relationship between ERV and annual bilateral FDI flows in the United States for the period of 1963-1978 using a time series data on the U.S. Goldberg \& Kolstad (1995) have carried out an extensive study about the impact of exchange rate volatility on FDI and their finding was in line with the work of Cushman (1985).

Furthermore, Chowdhury \& Wheeler (2008) examined the impact of real exchange rate volatility on FDI inflows for four developed G-7 countries. The findings showed that ERV is positively correlated to FDI flow and statistically significant in three of the sampled countries. Moreover, a study carried out by Dhakal et al. (2010) supported the findings of previous studies and confirmed the positive relationship between ERV on FDI.

On the other side, numerous studies also found a negative relationship between exchange rate volatility and FDI. Campa (1993) found that volatility of 
exchange rate negatively affects FDI for the US. In addition, Dixit and Pyndick (1994) took the lead and reached to the conclusion of the irreversibility literature with a clear justification to anticipate a negative correlation between exchange rate volatility and FDI flows. Moreover, Brzozowski (2006) investigated the impact of exchange rate uncertainty on FDI; the study included a sample of 32 countries. Fixed Effects OLS and GMM Arellano-Bond model were used, and GARCH method was applied for measuring exchange rate volatility. Results revealed that volatility in exchange rates has a negative impact on investment decisions. Similarly, Barrell et al. (2003) investigated the effect of exchange rate volatility on US FDI as the country-of origin in Europe and UK as host countries. Results showed that there is a strong negative correlation between exchange rate volatility in UK and Europe and US FDI which supported the results of previous studies.

Numerous studies conducted by Ullah et al. (2012), Dal Bianco \& To Loan (2017); Khan et al. (2017) also corroborated with the previous studies that exchange rate volatility has a negative impact on FDI.

However, some scholars also found mixed results as well as null relationship which made the impact of exchange rate volatility on FDI to be an increasingly ambiguous topic in the literature. In a study by Bouoiyour \& Rey (2005), a negative insignificant relationship between exchange rate volatility and FDI was found. Moreover, a research by Chaudhary et al. (2012) selected a sample of Asian economies and results revealed a mixed trend of the effect of exchange rate volatility on foreign direct investment in some of the sampled countries while the relationship between the two variables in nearly half of the sampled countries was not depicted.

\subsubsection{Market Size of Home Country}

The basic gravity model considers that market size of source countries increases FDI which is one of the important determinants that positively impacts FDI. Subsequently, Jorgenson in 1963 developed the market size hypothesis which claims that the larger the market size, the more FDI. The greater the size of the market in the country of origin, the larger the companies that are able and have the motives to expand in a foreign country. The market size is used as a proxy for the number of companies located in home country that can expand internationally.

In other words, there is a positive relationship between country-of-origin market size and outflow of FDI [Ajami \& Barniv (1984); Tallman (1988); Loree \& Guisinger (1995); Grosse \& Trevino (1996); Stone \& Jeon (2000); Barrell et al. (2017)]. Similarly, Kahouli \& Maktouf (2015) and Jena \& Mishra (2018) employed the gravity model, and the study supported the previous studies that argued that market size of source countries increases FDI inflows to host countries.

However, evidence regarding the effect of home country market size is indecisive as many studies indicate conflicting results. As mentioned by Liu et al. 
(1997), a study conducted by Pitelis (1996) claimed that the decision of firms located in home countries to invest overseas is mainly due to the lack of domestic demand. As market size variable can be utilized as a proxy for aggregate demand, thus, a negative relationship between country-of-origin market size and the amount of FDI in the host country may be expected. Furthermore, studies conducted by Thomas \& Grosse (2001) and Liu (2010) corroborated with the previous studies which revealed a negative relationship between the market size in home country and the level of FDI to host country.

On the other hand, Kimino et al. (2007) found that market size of source countries is statistically insignificant.

\subsubsection{Market Size of Host Country}

The basic gravity model for FDI claims that market size of host country is one of main determinants of FDI, and the model suggests that the larger the market size, the more FDI to host countries.

According to a study by Majeed \& Ahmad (2009), host countries with high demand, good economic conditions, and market ability to absorb new investments are the elements that motivate firms located in source countries to invest in these countries. This study found a positive association between market size and FDI inflows and revealed that the larger the market size of the host country, the greater FDI inflows. This finding is also supported by the studies conducted by Asmah \& Andoh (2013); Azhar et al. (2015); Barrell et al. (2017) and Jena \& Mishra (2018).

However, Ellahi (2011) investigated the impact of market size on inward FDI to Pakistan and covered the period from 1980 to 2010, following the assumption that increased growth in the host country will result in an increase in FDI. The results revealed that market size of host country negatively impacts FDI inflows to Pakistan which contradicted the previous studies.

\subsubsection{Geographic Distance}

According to the literature, there is a negative relationship between geographic distance and FDI inflows in the host country. As indicated by Grosse and Trevino (1996), the larger the distance between the host and home country is, the higher the cost of getting information and controlling an affiliate will be in the host country market, thus, the lower inward FDI in the host country will be.

Furthermore, Gao (2005) employed the gravity model, and results revealed that large distance between China as host country and source countries decreases inward FDI. This study corroborates with the gravity model that suggests that there is an inverse relationship between distance and FDI.

Numerous studies supported the findings of the negative relationship between geographic distance and FDI such as the studies conducted by Ismail (2009); Miroslav (2009); Barrell et al. (2017); Jena \& Mishra (2018) and Hanh (2020).

Conversely, Liu et al. (1997) in their study revealed that the geographical distance is statistically insignificant, and they attributed this result to the progress in transportation and communication in a country. 
Furthermore, the results of Thomas and Grosse (2001) showed the existence of a positive relationship between geographic distance and FDI.

\subsubsection{Existing Bilateral Trade}

There is a debate and contradicting results in both the literature of FDI and international trade on whether FDI and trade are substitutes or complements. The theory of conventional neoclassical trade proposes that companies that need to operate in another market are motivated by the need for penetrating a new market while faced by high trade barriers, thus, FDI is likely to substitute for trade which reveals a negative relationship between existing bilateral trade and FDI.

On the other hand, if there is an increasing volume of trade between host and source countries as well as FDI through extracting resources and outsourcing, there is a positive relationship between bilateral trade and FDI which means that they are complements. Studies conducted by [Ajami \& Barniv (1984) and Ray (1989) and Kahouli \& Omri (2017) revealed the positive relationship between bilateral trade and FDI. This can be demonstrated with the rationale that firms located in the country-of-origin can reach a market in host country through exporting to foreign country and/or through production in the host country.

Conversely, by employing the gravity model; Roberts and Almahmood (2009) investigated the impact of bilateral trade on foreign direct investment (FDI) inflows to Saudi Arabia. It was shown that there is no relationship between foreign direct investment and trade in Saudi Arabia.

\subsubsection{Relative Borrowing Cost}

The cost of borrowing money is the financing cost from financial institutions. Firms of home country are the one who bears the financing cost, thus, according to Aliber (1970), low financing costs help firms located in the home country to have a cost advantage for investing in a country as it is one of the main sources for a firm to have a competitive advantage over other competitors located in the host country. Therefore, the lower the cost of borrowing in the country of origin is, the more the inward FDI in the host country will be.

The study conducted by Ajami \& Braniv (1984) confirmed that the higher the interest rate in the country of origin, the lower FDI inflows in U.S as a host country. Furthermore, the findings of Grosse \& Trevino (1996) supported the findings of Ajami \& Braniv (1984). Numerous studies corroborated the negative association between the cost of borrowing and inward FDI of the host country [Thomas \& Grosse (2001); Pan (2003); Liu (2010); Imansyah (2017)].

On the other hand, Liu et al. (1997), contrary to other previous studies, found that the lower the borrowing costs in China as a host country, the higher inward FDI in China. This alludes that firms located in home country are not only using their own source of financing, but using the capital of the host country to finance their investment in China since they find that interest rates in the host country are lower relative to the interest rate in home country. Results found that the cost of borrowing is statistically insignificant. 
Furthermore, Kimino et al. (2007) examined the determinants of FDI inflows to Japan. Results revealed the positive relationship between lending rate and FDI which means that an increase in the lending rate of the source country increases FDI flows to the host country.

Additionally, a study conducted by Asiamah et al. (2019) examined the determinants of inward FDI to Ghana covering the period between 1990 and 2015. The findings of this study revealed the negative and significant impact of interest rate on inward FDI. In other words, the higher the interest rate in host country, the lower FDI inflows to Ghana due to higher borrowing cost.

\subsubsection{Labor Productivity}

Bellak, Leibrecht, \& Riedl (2008) using the gravity model investigated the impact of labor wage and labor productivity on inward FDI to CEEC countries. The study revealed that overall labor costs as well as labor productivity are essential determinants behind FDI in the CEEC countries. Therefore, the study found the existence of a positive relationship between labor productivity and inward FDI.

Further, many studies confirmed the positive impact of labor productivity on inward FDI such as the study conducted by Rodríguez \& Pallas (2008), Kayam \& Hisarciklilar (2009).

Similarly, Hoang \& Bui (2015) focused on ASEAN countries for the period from 1991 to 2009, and the results showed that low labor cost does not attract FDI to the region, while labor productivity is more important for investors which is significant.

In the same context, Beloucif et al. (2020) analyzed the impact of labor productivity as one of FDI determinants on inward FDI to South and South-east Asia. Findings of this study showed the positive relationship between labor productivity and inward FDI in both regions.

\subsubsection{Corruption}

Corruption is considered as an institutional barrier to FDI since investors consider whether to invest in a foreign country based on the perceived level of corruption.

Ismail (2009) used a semi-gravity model to explore the determinants influencing FDI. Results of the study found that corruption has a significant and positive impact on inward FDI which means the higher the corruption index, the more FDI flows. The corruption index used means that the higher the index the less corrupted the country.

As bribery is costly, hence firms are discouraged and not willing to manage a business in a country where there is a high corruption level. This is supported by Egger \& Winner (2006) as they found a negative relationship between corruption in the host country and their inward FDI.

In contrast, a research by Lui (1985) discussed that firms, putting high value on time, most probably pay bribes to quicken business process. Accordingly, 
corruption can be considered as a way for allocation efficiency. Moreover, a study conducted by Moustafa (2020) revealed that foreign direct investment inflows to Egypt are positively correlated with the amount of corruption in the country.

Conversely, a recent study by Elshazly (2020) examined the corruption variable and the results showed the insignificant effect of corruption on FDI inflows.

\subsubsection{Cultural Differences}

The more cultural differences found between the host and home countries, the higher the difficulty of managing an affiliate located in the host country market, hence, the lower inward FDI in the host country.

Furthermore, Grosse \& Trevino (1996) confirmed the significant negative correlation between the two variables. This finding was demonstrated by being closer to the target market, in fact, it provides some advantages over being further away.

Additionally, Gagne (2018) focused primarily on the impact of cultural distance on foreign direct investment outflows from China to African countries. Using the Kogut and Singh index and the four Hofstede dimensions, the findings showed that cultural distance has a statistically significant negative impact on FDI flows to Africa.

Previous empirical studies have focused mainly on developed economies as source countries of FDI and developing countries as host countries; however, additional insight into foreign direct investment can be gained by an examination of not only developed countries but also developing countries as source countries which is currently lacking in the literature. Also by reviewing the academic literature, it is found that various studies have investigated the effect of FDI determinants on total FDI inflows to host country. However, only a few studies have tackled the issue of relative FDI determinants between the source and host countries and how it affects inward FDI to host country such as the studies conducted by Grosse and Trevino (1996); Thomas and Grosse (2001); Kimino et al. (2007); Dauti (2015); Jena \& Mishra (2018). Empirically, this study aims to fill the gap on the academic studies by focusing on Egypt as a host country of FDI during the period of 2005-2019 with the use of secondary data by analyzing whether relative real exchange rate volatility and other FDI dimensions impact Egypt inward FDI positively or negatively. The empirical results will be compared to the previous results across different studies to see whether they are consistent or not. This in turn will give significant insights to policymakers in setting their policies in attracting FDI inflows to Egypt.

\section{Data and Methodology}

\subsection{Variables Description and Calculations}

In this research, the dependent variable is FDI, while the independent variables are relative real exchange rate, relative real exchange rate volatility, home country market size, host country GDP, bilateral trade, geographic distance, relative 
cost of borrowing, relative labor productivity, relative corruption, and cultural differences.

Table 1 shows the research variables and their calculations.

\subsection{Study Hypotheses}

The following hypotheses are derived from the analysis of different studies made by previous researchers on this spot of relationship. These hypotheses are to be tested to determine the impact of real exchange rate volatility and other determinants on FDI inflows to Egypt.

H1: There is a significant relationship between source countries with an appreciating currency and inward FDI flows into Egypt.

H2: There is a significant relationship between relative Exchange Rate Volatility and inward FDI flows into Egypt.

H3: There is a significant relationship between market size of home country and inward FDI flows into Egypt.

H4: There is a significant relationship between market size of host country and inward FDI flows into Egypt.

H5: There is a significant relationship between the geographic distance between the country of origin and inward FDI flows into Egypt.

H6: There is a significant relationship between existing bilateral trade and inward FDI flows into Egypt.

H7: There is a significant relationship between cost of borrowing and inward FDI flows into Egypt.

H8: There is a significant relationship between labor productivity and inward FDI flows into Egypt.

H9. There is a significant relationship between corruption and inward FDI flows into Egypt.

H10. There is a significant relationship between the cultural differences and inward FDI inflows into Egypt.

\subsection{Research Model}

According to empirical studies, relatively few papers attempted to investigate FDI using the gravity model in order to examine the effects of country-level on FDI [Miroslav (2009), Dauti (2015), Barrell et al. (2017), Jena \& Mishra (2018), Balaban et al. (2019)]. A number of variables were included in these studies; they were actually added to the basic gravity model. Adding various variables ends up by having augmented gravity models which lead to a better explanation and clear results.

The augmented gravity model for FDI is as follows:

$$
\begin{aligned}
F D I_{i j t}= & \alpha+\beta_{1} R E R_{i j t}+\beta_{2} R E R V_{i j t}+\beta_{3}\left(G D P_{j t}\right)+\beta_{4}\left(G D P_{i t}\right)+\beta_{5}\left(D I S T_{i j}\right) \\
& +\beta_{6} C B_{i j t}+\beta_{7} B T R A D E_{i j t}+\beta_{8} C O R R_{i j t}+\beta_{9} L P R O D_{i j t}+\beta_{10} C D_{i j}+e_{i j t}
\end{aligned}
$$

where: 
Table 1. Variables definition and measurements.

\begin{tabular}{|c|c|c|c|}
\hline Variables & Indicators & Measurement & Reference \\
\hline \multicolumn{4}{|c|}{ Independent variables } \\
\hline $\begin{array}{l}\text { Real } \\
\text { Exchange rate }\end{array}$ & RER & $\begin{array}{c}\text { Relative average annual real exchange rate, } \\
\text { (country of origin's currencyl Egyptian pound) - CPI } \\
\text { of each sample country }\end{array}$ & $\begin{array}{l}\text { Liu et al. (1997); } \\
\text { Thomas \& Grosse (2001), } \\
\text { Kimino et al. (2007) }\end{array}$ \\
\hline $\begin{array}{l}\text { Real Exchange } \\
\text { rate volatility }\end{array}$ & RERV & $\begin{array}{l}\text { Monthly real exchange rate volatility using } \operatorname{GARCH}(1,1) \\
\qquad E R V_{t}=\frac{1}{12} \times\left(h_{1}+h_{2}+\cdots+h_{12}\right)\end{array}$ & $\begin{array}{l}\text { Ullah et al. (2012), } \\
\text { Azhar et al. (2015), } \\
\text { Balaban et al. (2019) }\end{array}$ \\
\hline $\begin{array}{l}\text { Home } \\
\text { market size }\end{array}$ & $\mathrm{GDP}_{j}$ & Real GDP of source country & $\begin{array}{l}\text { Grosse \& Trevino (1996), } \\
\text { Kimino et al. (2007), } \\
\text { Barrell et al. (2017) }\end{array}$ \\
\hline $\begin{array}{l}\text { Host country } \\
\text { market size }\end{array}$ & $\mathrm{GDP}_{\mathrm{i}}$ & Real GDP of the host country & $\begin{array}{l}\text { Majeed \& Ahmad (2009), } \\
\text { Ellahi (2011), } \\
\text { Barrell et al. (2017) }\end{array}$ \\
\hline $\begin{array}{l}\text { Existing } \\
\text { bilateral trade }\end{array}$ & BTRADE & $\begin{array}{l}\text { Exports from the home country into Egypt and } \\
\text { imports into the home country from Egypt, annually }\end{array}$ & $\begin{array}{l}\text { Grosse \& Trevino (1996), } \\
\text { Thomas \& Grosse (2001) }\end{array}$ \\
\hline \multirow{2}{*}{$\begin{array}{l}\text { Relative cost of } \\
\text { Borrowing }\end{array}$} & \multirow{2}{*}{$\mathrm{CB}$} & $\begin{array}{l}\text { Source country real lending interest rate-real lending } \\
\text { of Egypt interest at year-end, annually. }\end{array}$ & $\begin{array}{l}\text { Zhao (2003), } \\
\text { Kimino et al. (2007), } \\
\text { Alon et al. (2012), }\end{array}$ \\
\hline & & Real lending interest rate $=$ Lending rate minus inflation & $\begin{array}{l}\text { Liu et al. (1997), } \\
\text { Kimino et al. (2007) }\end{array}$ \\
\hline $\begin{array}{l}\text { Relative Labor } \\
\text { Productivity }\end{array}$ & LPROD & $\begin{array}{l}\text { Calculated as real GDP in US\$ divided } \\
\text { by total employed person of respective year }\end{array}$ & $\begin{array}{l}\text { Hoang \& Bui (2015), } \\
\text { Hafeez (2016), } \\
\text { Beloucif et al. (2020) }\end{array}$ \\
\hline Corruption & CORR & $\begin{array}{c}\text { Measured by the Corruption Perception Index (CPI), } \\
\text { the absolute difference in corruption } \\
\text { between the host and the home country }\end{array}$ & $\begin{array}{l}\text { Habib \& Zurawicki (2002), } \\
\text { Egger \& Winner (2006) }\end{array}$ \\
\hline $\begin{array}{l}\text { Geographic } \\
\text { distance }\end{array}$ & DIST & $\begin{array}{l}\text { The distance from the home } \\
\text { country capital to the capital of Egypt. }\end{array}$ & $\begin{array}{c}\text { Thomas \& Grosse (2001), } \\
\text { Roberts \& Almahmood (2009), } \\
\text { Hanh (2020) }\end{array}$ \\
\hline $\begin{array}{l}\text { Cultural } \\
\text { distance }\end{array}$ & $\mathrm{CD}$ & $\begin{array}{c}\text { Hofstede }(1980) \\
\text { Euclidean distance formula } \\
E D=\sqrt{\sum_{k=1}^{4} \frac{\left(I_{k i}-I_{k j}\right)^{2}}{V_{k}}}\end{array}$ & $\begin{array}{l}\text { Fuentelsaz et al. (2020) } \\
\text { Korzeb (2021) }\end{array}$ \\
\hline & & Dependent variable & \\
\hline $\begin{array}{l}\text { Foreign direct } \\
\text { investment }\end{array}$ & FDI & $\begin{array}{l}\text { Annual FDI inflow from source country } \\
\text { to host country in millions of dollars }\end{array}$ & $\begin{array}{l}\text { Pan (2003), Zhao (2003), } \\
\text { Kimino et al. (2007), } \\
\text { Liu (2010), } \\
\text { Parajuli \& Kennedy (2010), } \\
\text { Jena \& Mishra (2018) }\end{array}$ \\
\hline
\end{tabular}


$F D I_{i j t}$ : stands for the foreign direct investment in Egypt $i$ from country $j$ at time $t$.

$R E R_{i j t}$ : stands for the relative real exchange rate at time $t$.

$R E R V_{i j t}$ : stands for the relative real exchange rate volatility at time $t$.

$G D P_{j t}$ : stands for the real gross domestic product of country $j$ at time $t$.

$G D P_{i t}$ : stands for the real gross domestic product of $i$ at time $t$.

$D I S T_{i j}$ : stands for the geographic distance between country $i$ and country $j$.

$C B_{i j t}$ : stands for the real interest rate differential between country $i$ and country $j$ at time $t$.

$B T R A D E_{i j t}$ : stands for the bilateral trade between country $i$ and country $j$ at time $t$.

$\operatorname{CORR}_{i j t}$ : stands for the relative corruption index between country $i$ and country $j$ at time $t$.

$L P R O D_{i j t}$ : stands for the relative labor productivity between country $i$ and country $j$ at time $t$.

$C D_{i j}$ : stands for the cultural distance between country $i$ and country $j$.

i: Refers to host country.

$j$ : Refers to source country.

$e_{i j t}:$ is the error term.

For testing the gravity model, dynamic panel data estimation is used which is considered as a standard econometric tool employed in the empirical literature. Since the endogeneity problem is ignored when using the traditional OLS panel data analysis with either fixed effect or random effect in previous studies, the study of Liu (2010) applied the lately developed System Generalized Method of Moments (System GMM) approach for an estimation of the panel data if the endogeneity exists. There are two estimator techniques; the difference GMM and the system GMM estimators, both are designed for panel analysis for small time periods and a large number of independent variables. In this study, the Difference GMM approach as a regression method is applied for executing the analysis since this study is performed to test the relationship between exchange rate volatility as well as other determinants and FDI inflows for a sample of source and host countries. The statistical techniques are conducted using E-views version 8 and Stata version 13 .

The descriptive research model is represented in Figure 1 to describe the impact of relative exchange rate volatility and multidimensional determinants on inward FDI.

\subsection{Sampling and Data Collection}

All the data used in this study are collected from secondary sources, International Financial Statistics (IFS), Direction of Trade Statistics (DOTS), World Bank, Transparency International, Central Bank of Egypt and Central banks of the sampled source countries. Data are tested from the year 2005 until 2019, so the effect of the decision of floating the Egyptian pound in 2016 on FDI will be clarified. According to the data available for the cost of borrowing for Euro area 


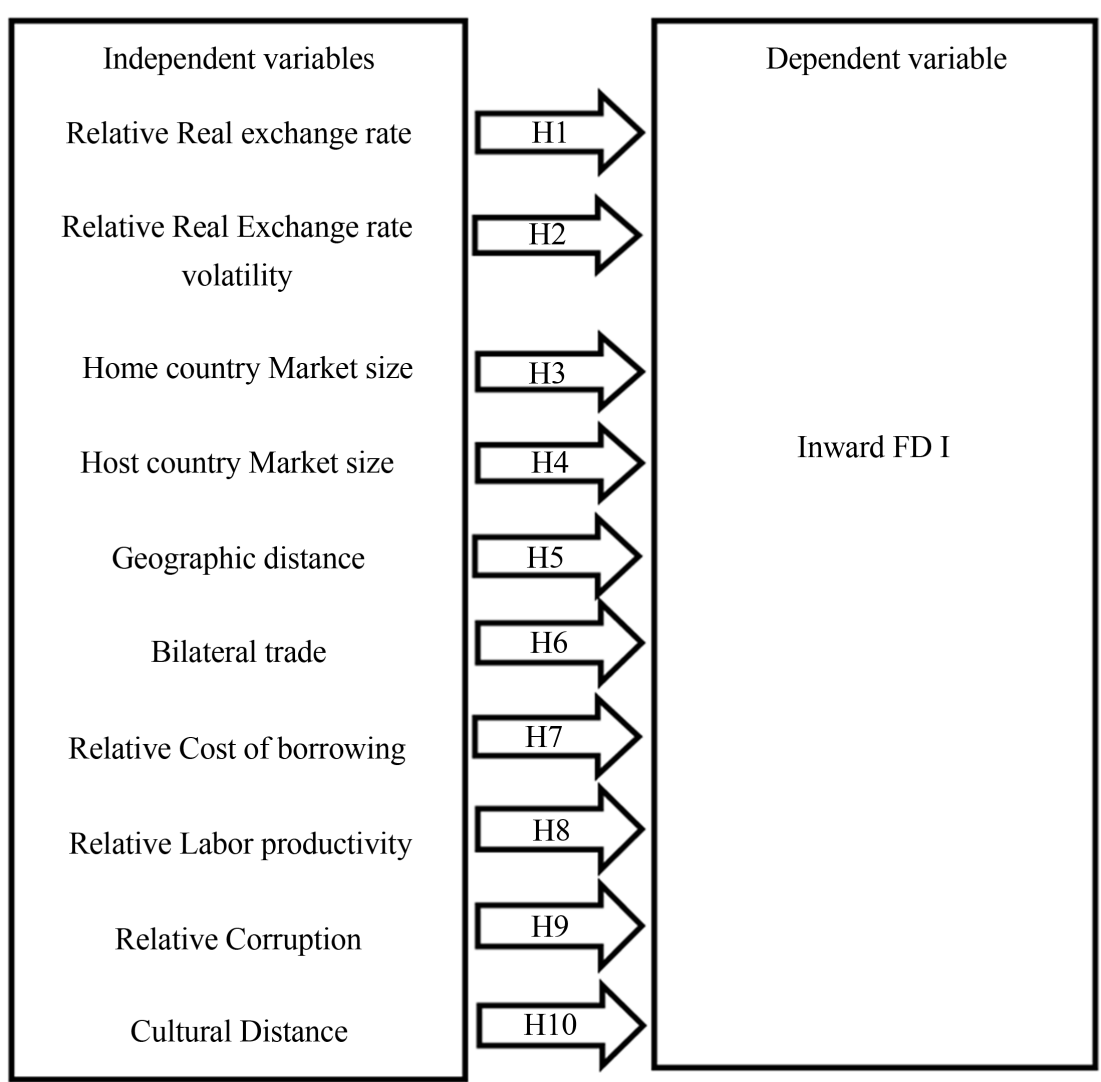

Figure 1. The relationship between independent variables and the dependent variable (Descriptive research model).

countries, the latter do not consider the lending rate of each country separately, but there is a harmonized euro rate for loans for non-financial corporation for each country which is used in this study as a proxy for the cost of borrowing for Euro area countries as clarified by Camba-Mendez et al. (2016). The chosen sample in this study is 42 source countries from developed and developing countries from total 52 countries and Egypt as the host country for FDI over the period 2005-2019. After excluding 10 countries according to data availability and accessibility, a sample of 42 source countries is obtained for a period of 15 years leaving us with 630 observations.

A descriptive statistic is executed to describe the relevant variables in the study. Summary Statistics is used to show the Mean, Median, Standard Deviation, Minimum and Maximum values of all variables. Next, unit root test is applied first for individual time series using $\mathrm{lm}$, Pesaran and Shin $\mathrm{W}$, and then the Augmented Dickey-Fuller (ADF) test is done for each country individually. Subsequently, the volatility of exchange rate is conducted by using GARCH ( 1 , 1), then a panel unit root test is conducted to check for the stationarity using the Levin, Lin and Chu (LLC) test. For testing the gravity model, dynamic panel data estimation is used which is considered as a standard econometric tool employed in the empirical literature. The Difference GMM approach as a regression method is applied for executing the analysis since this study is performed to test the 
relationship between exchange rate volatility as well as other determinants and FDI inflows for a sample of source countries and host country.

\subsection{Measurement}

\section{Modelling Volatility}

This study measures the volatility of the real exchange rate using GARCH model developed by Bollerslev (1986). Accordingly, $\operatorname{GARCH}(1,1)$ model is used in this study firstly as it is the simplest case of GARCH as mentioned by Brooks (2008). Secondly, many studies measured the volatility and found out that GARCH (1, 1) model is the most preferable one for all countries [Coleman \& Tettey (2008) and Del BO (2009)].

$$
\begin{gathered}
R E R_{t}=\sum_{i=1}^{p} \delta_{i} R E R_{t-i}+\varepsilon_{t} \\
h_{t}=\alpha_{0}+\alpha_{1} \varepsilon_{t-1}^{2}+\beta_{1} h_{t-1}
\end{gathered}
$$

Equations (1) and (2) are used to construct the indices of the monthly exchange rate volatility using $\operatorname{GARCH}(1,1)$. Equation (1) is the mean equation, where $R E R_{t}$ is the real exchange rate, $\varepsilon_{t}$ is the error term and the value of $p$ is placed to check that the estimated residuals are free from serial correlation. Equation (2) is the conditional variance $\left(h_{t}\right), \alpha_{0}$ is the constant term, $\alpha_{1}$ is the parameter coefficient of the autoregressive lag, $\alpha_{1} \varepsilon_{t-1}^{2}$ is the information about volatility during the prior period as the lag of the squared residual from the mean Equation (1), $\beta_{1}$ is the parameter coefficient of the moving average lag, $\beta_{1} h_{t-1}$ is the fitted variance from the model during the previous period/the previous forecast error variance which is the GARCH term. Finally, an annual measure for the evolution of monthly real exchange rate volatility is employed by the sum of the monthly values of $h_{t}$ for each year for each country in the sample, monthly data collected from International Financial Statistics for each country and it is computed as follows:

$$
E R V_{t}=\frac{1}{12} \times\left(h_{1}+h_{2}+\cdots+h_{12}\right)
$$

\section{Findings and Analysis}

\subsection{Descriptive Statistics}

Table 2 illustrates the descriptive analysis for the research variables using the mean, median, maximum, minimum and standard deviation for the research variables. The minimum value for the research dependent variable FDI by source country is $\$-149.650$ million, this value pertains to Luxembourg FDI inflows to Egypt in 2018. While the maximum FDI inflow was achieved by United Kingdom in 2016. Regarding the mean value of FDI inflows by source countries, it revealed to be $\$ 268.083$ million, a median of $\$ 17.300$ million with a standard deviation of $\$ 817.75809$ million.

As for the independent variables, the relative real exchange rate has a mean of $\$ 10.758$, a median of $\$ 0.177$ and a standard deviation of $\$ 44.369$, with a minimum 
Table 2. Descriptive statistics 2005-2019.

\begin{tabular}{|c|c|c|c|c|c|c|}
\hline & $\begin{array}{l}\text { Number of } \\
\text { Observation }\end{array}$ & Mean & Median & Std. Dev & Minimum & Maximum \\
\hline FDI & 630 & 268.08325 & 17.30000 & 817.75809 & -149.65000 & 5731.55000 \\
\hline $\begin{array}{c}\text { Relative } \\
\text { RER }\end{array}$ & 630 & 10.75835 & 0.17766 & 44.36963 & 0.01848 & 362.34669 \\
\hline $\begin{array}{c}\text { Relative } \\
\text { RERV }\end{array}$ & 630 & 2.99567 & 0.00003 & 24.84118 & 0.00000 & 403.81778 \\
\hline $\begin{array}{c}\text { GDP } \\
\text { Home }\end{array}$ & 630 & $1,333,219,004,149.00$ & $388,357,965,353.14$ & $2,774,343,052,844.35$ & $7,765,375,522.42$ & $18,300,385,513,295.60$ \\
\hline GDP & & & & & & \\
\hline $\begin{array}{c}\text { Host } \\
\text { country }\end{array}$ & 630 & $229,455,463,151.92$ & $227,808,827,464.09$ & $39,144,418,104.54$ & $162,281,672,226.38$ & $302,183,451,076.56$ \\
\hline BTRADE & 630 & 1660.94359 & 587.27237 & 2292.08347 & 3.14681 & $13,888.55012$ \\
\hline CB & 630 & 1.11881 & 1.25103 & 5.90587 & -30.81997 & 30.47281 \\
\hline $\begin{array}{l}\text { Relative } \\
\text { LPROD }\end{array}$ & 630 & 7.75971 & 6.73908 & 5.40384 & 0.13678 & 32.46902 \\
\hline CORR & 630 & 30.26508 & 30.0 & 18.35807 & -10.0 & 65.0 \\
\hline DIST & 42 & 3704.94850 & 2961.58300 & 2853.30117 & 494.24820 & $14,279.40000$ \\
\hline $\mathrm{CD}$ & 42 & 2.26624 & 2.28064 & 1.10600 & 0.39570 & 4.38045 \\
\hline
\end{tabular}

value of relative real exchange rate between Kuwait as source country and Egypt as a host country of $\$ 0.018$, while the highest relative real exchange rate between Lebanon as source country and Egypt of \$362.3467 in 2005.

With regards to the real exchange rate volatility, the maximum value is $\$ 403.81778$ which pertains to Korea in 2017 , and this can be explained by the floating of the Egyptian pound that happened by the end of 2016 in Egypt. While the minimum value of exchange rate volatility is approximately zero which is relative between Jordan and Egypt, and also Kuwait and Egypt, a mean of $\$ 2.99567$, median of $\$ 0.00003$, and a standard deviation of $\$ 24.84118$.

Whereas the Real GDP of all source countries, the mean value, revealed to be $\$ 1333.219$ billion with a median that is equal to $\$ 388.36$ billion and standard deviation of $\$ 2774.343$ billion. Regarding the minimum value of GDP of $\$ 7.765$ billion pertains to Malta in 2005 , and the highest value of $\$ 18,300.39$ was achieved by United States in 2019.

For the Real GDP of Egypt as the host country had a mean value of \$229.46 billion, a median that is equal to $\$ 227.81$ billion, and standard deviation of $\$ 39.14$ billion. While the minimum of GDP \$ occurred in 2005 to be $\$ 162.28$ billion and the highest value of GDP was achieved in 2019 to reach $\$ 302.18$ billion.

Regarding the bilateral trade between each source country and Egypt, data showed that the maximum bilateral trade is between China and Egypt in 2018 to be $\$ 13,888.550$ while the minimum value of $\$ 3.147$ between Lithuania and Egypt in 2005 , with a mean of $\$ 1660.944$, a median of $\$ 587.272$ and standard deviation of $\$ 2292.083$. 
The cost of borrowing which is the lending rate differential between source countries and Egypt had a mean of $1.119 \%$, a median of $1.251 \%$ and a standard deviation of $5.906 \%$ while the minimum value of lending rate differential was $-30.819 \%$ between Qatar as a source country and Egypt in 2005 and a maximum value of lending rate differential equals to $30.473 \%$ also between Qatar and Egypt.

With regard to labor productivity, it tends to have an average of $\$ 7.76$, a median of $\$ 6.739$ with a standard deviation of $\$ 5.404$. As for the minimum value of relative labor productivity between Spain and Egypt, it is found to be equal to $\$ 0.137$, while the maximum value of $\$ 32.47$ pertains to Luxembourg relative to Egypt.

As for the relative corruption data, it indicates a mean of 30.265 , a median of 30 , and standard deviation that is equal to 18.358 . Regarding the minimum value of relative corruption, it is equal to - 10 between Lebanon and Egypt in 2014, and a maximum value equals to 65 between Denmark and Egypt for the years 2007, 2008, 2009 and 2011; and also for Sweden in 2008.

Concerning the geographic distance between source countries and Egypt, a mean value of $3704.949 \mathrm{~km}$, a median of $2961.58300 \mathrm{~km}$, and a standard deviation that is equal to $2853.301 \mathrm{~km}$ were depicted. As for the maximum value of distance of 14,279.400 km which is the distance between Australia and Egypt, a minimum value of $494.24820 \mathrm{~km}$ is the distance between Jordan and Egypt.

Finally, the cultural distance had a mean value of 2.266, a median of 2.281 and a standard deviation of 1.106 while the maximum value of cultural distance equals to 4.380 representing the cultural distance between Egypt and Denmark, and a minimum value of cultural distance of 0.396 between Egypt and Bulgaria.

\subsection{Unit Root Test}

Among the existing panel unit root, $\mathrm{lm}$, Pesaran and Shin $\mathrm{W}$-stat is used. As in this study, there are 42-time series for each variable in each source country, and some countries may have a stationarity in their data while other countries may not have a stationarity problem.

Table 3 presents unit root test for panel data which is used for individual time series and for all the sampled countries. First, the cross sectional unit root test at level is employed that includes in general all the sampled countries during 2005-2019 for the relative real exchange rate variable. As, H0 suggests that there is an individual unit root process where $p>0.05$ and $p$ value equals to 1 , thus, the null hypothesis of unit root cannot be rejected at the $1 \%$ significance, ensuring that relative real exchange rate in their level form is non-stationary. In order to reach the stationarity, the first difference is taken and $p$ value is less than 0.05 , and it is approximately zero, thus reject $\mathrm{H} 0$, and there is no significant effect and there is no stationary problem in this case.

Then, the Augmented Dickey-Fuller (ADF) test for each country individually was conducted. Unit root test taken at level, shows that the $p$ value $>0.05$ for all the sampled countries, hence the null hypothesis cannot be rejected, and there is 
Table 3. Unit root test: $1 \mathrm{~m}$, Pesaran and Shin W-stat.

\begin{tabular}{|c|c|}
\hline Unit root test at level & Unit root test at the first difference \\
\hline $\begin{array}{l}\text { Null hypothesis: Unit root } \\
\text { (individual unit root process) }\end{array}$ & $\begin{array}{l}\text { Null hypothesis: Unit root } \\
\text { (individual unit root process) }\end{array}$ \\
\hline Series: Relative Real Exchange Rate & Series: D (Relative Real Exchange Rate) \\
\hline Sample: 2005M01 2019M12 & Sample: 2005M01 2019M12 \\
\hline Exogenous variables: Individual effects & Exogenous variables: Individual effects \\
\hline Automatic selection of maximum lags & Automatic selection of maximum lags \\
\hline $\begin{array}{l}\text { Automatic lag length selection } \\
\text { based on SIC: } 0 \text { to } 2\end{array}$ & $\begin{array}{l}\text { Automatic lag length selection } \\
\text { based on SIC: } 0 \text { to } 1\end{array}$ \\
\hline Total number of observations: 7569 & Total number of observations: 7546 \\
\hline \multicolumn{2}{|c|}{ Cross-sections included: 43} \\
\hline \multicolumn{2}{|c|}{ Method: lm, Pesaran and Shin W-stat } \\
\hline Prob. ${ }^{* *}=1.0000$ & Prob. ${ }^{* *}=0.0000$ \\
\hline
\end{tabular}

a significant effect which means that there is a stationarity problem in the data. Accordingly, taking the first difference, the $p$ value for all the sampled countries is approximately equal to zero, which means that the $p$ value is less than 0.05 , hence $\mathrm{HO}$ is rejected, and there is no significant effect of stationarity problem.

\subsection{Panel Unit Root Test}

Almost all economic variables are non-stationary at their level form which causes inconsistencies in the coefficients and spurious empirical results. Panel unit root tests are more robust than time-series unit root tests because the variance across countries adds significant information to the variation across time, potentially leading to more precise parameter estimates (Taylor \& Sarno, 1998). Therefore, Levin, Lin \& Chu $t^{*}$ is used to check for the stationarity of panel data which means the stationarity of each variable for all the sampled countries. Taking the panel unit root test at level for the dependent variable of this study-FDI- $p$ value $>0.05$ and equals 1 , hence the null hypothesis cannot be rejected at the $1 \%$ significance. Then, to reach for the stationarity of all countries, a panel unit root test is done using first difference, the $p$-value equals 0.9923 which is more than 0.05 and the null hypothesis is rejected. Thus, a panel unit root test taking the second difference, and found that $p$-value is approximately zero which means that the $p$-value $<0.05$, thus, the null hypothesis is rejected, and the stationarity for all the 42 sampled countries is reached in the second difference. The relative exchange rate volatility, bilateral trade, cost of borrowing, and relative labor productivity have reached the stationarity at level while, the relative exchange rate variable, real GDP of home country, and corruption have reached the stationarity at the first difference, and the only variables that reached the stationarity at the second difference is Real GDP of host country. In conclusion, relying 
on Levin, Lin \& Chu $\mathrm{t}^{\star}$ for the stationarity of panel data, it becomes clear that all the variables in this study reach the stationarity at the second difference (Table 4).

\subsection{Testing the Research Hypotheses}

As the variables of this study are not static, this means that the observation of a variable of the certain period impact the observation of this variable in the following period, thus, dynamic model is estimated. This study conducted the difference General Method of Moments diff-(GMM) estimation technique suggested by Arellano and Bond (1991) using two-step strategy based differentiation and instrumentation. Table 5 presents the main results of the research model showing that the model as a whole is significant according to Wald chi square test statistic where $p=0.0000$. The first part of the table demonstrates the variables that have been found to have a significant impact on inward FDI to Egypt. As it can be depicted from the table, all the independent variables except relative real exchange rate and cultural distance have significant effect on inward FDI to Egypt over the period of the study. Arellano-Bond test for AR (1) and the Arellano-Bond test for AR (2) are employed measure first- and second-degree serial correlations, where the $p$ value $=0.0540$, and the $p$ value of $\mathrm{AR}(2)=$ 0.1488 , thus a second-degree serial correlation cannot be rejected.

H1: There is a significant relationship between source countries with an appreciating currency and inward FDI flows into Egypt.

As it can be depicted from Table 5, relative real exchange rate has an insignificant effect on inward FDI to Egypt ( $\beta=0.116486, p=0.646$ ), thus the first

Table 4. Panel unit root test: Levin, Lin \& Chu.

\begin{tabular}{cccc}
\hline \multirow{2}{*}{ Variable } & Unit root at level & $\begin{array}{c}\text { Unit root at } \\
\text { first difference }\end{array}$ & $\begin{array}{c}\text { Unit root at } \\
\text { second difference }\end{array}$ \\
\cline { 2 - 4 } FDI & 1.0000 & $\begin{array}{c}\text { Null: Unit root (assumes common root process) } \\
\text { Levin, Lin \& Chu } \text { t }^{*} \text { Prob. }\end{array}$ \\
RER & 1.0000 & 0.9923 & 0.0000 \\
RERV & 0.0000 & 0.0000 & 0.0000 \\
GDPHOME & 1.0000 & 0.0000 & 0.0000 \\
GDPHOST & 1.0000 & 0.0000 & 0.0000 \\
BTRADE & 0.0000 & 1.0000 & 0.0000 \\
CB & 0.0000 & 0.0000 & 0.0000 \\
LPROD & 0.0356 & 0.0000 & 0.0000 \\
CORR & 0.0001 & 0.0000 & 0.0000 \\
DIST & & 0.0000 & 0.0000 \\
CD & & Time invariant &
\end{tabular}


Table 5. Two-step difference (GMM) results dependent variable: inward FDI.

\begin{tabular}{|c|c|c|}
\hline Variable & $\begin{array}{c}\text { Coefficient } \\
\text { (Standard Error) }\end{array}$ & $p$ Value \\
\hline Relative real exchange rate & $\begin{array}{c}0.116486 \\
(0.2537517)\end{array}$ & 0.646 \\
\hline Relative real exchange rate volatility & $\begin{array}{c}0.1094829^{\star * *} \\
(0.0477805)\end{array}$ & 0.022 \\
\hline GDP of home country & $\begin{array}{c}7.56 \mathrm{e}-11^{\star \star *} \\
(1.33 \mathrm{e}-12)\end{array}$ & 0.000 \\
\hline GDP of host country & $\begin{array}{l}5.56 \mathrm{e}-10^{\star * *} \\
(2.64 \mathrm{e}-11)\end{array}$ & 0.000 \\
\hline Geographic distance & $\begin{array}{c}-0.0418228^{\star * *} \\
(0.0043226)\end{array}$ & 0.000 \\
\hline Bilateral trade & $\begin{array}{c}0.0304479^{\star * *} \\
(0.000501)\end{array}$ & 0.000 \\
\hline Relative cost of borrowing & $\begin{array}{c}0.7441286^{\star * *} \\
(0.0221266)\end{array}$ & 0.000 \\
\hline Relative labor productivity & $\begin{array}{c}11.18942^{\star * *} \\
(1.365747)\end{array}$ & 0.000 \\
\hline Relative corruption & $\begin{array}{l}4.638208^{\star * *} \\
(0.1647012)\end{array}$ & 0.000 \\
\hline Cultural distance & $\begin{array}{c}27.40587 \\
(25.28461)\end{array}$ & 0.278 \\
\hline Number of observations & 630 & \\
\hline Wald chi ${ }^{2}$ & $102,272.33$ & \\
\hline Number of countries & 42 & \\
\hline $\operatorname{AR}(2)$ & 0.1488 & \\
\hline
\end{tabular}

Notes: ${ }^{* *}$ is statistical significance at the $1 \%$.

hypothesis of the study has been rejected. This result is congruent with many studies that found no relation between real exchange rate and FDI inflows, such as the study conducted by Abdullah et al. (2006) that have studied the impact of relative exchange rate by taking the exchange rate of China as a host country relative to each of the ASEAN-5 source countries on FDI inflows into China. They similarly concluded that relative exchange rate has no significant impact on inward FDI to China. Moreover, Kimino et al. (2007) focused on FDI inflows to Japan from 17 source countries where the results showed that relative real exchange rate has no significant impact on FDI inflow to Japan.

In addition, De Vita \& Abbott (2008) concluded in studying the impact of real exchange rate on FDI flows to UK from seven major source countries for 1975-2001 period using GMM panel estimation technique that no statistical significant relationship between real exchange rate and FDI inflows to UK is found. 
The similarity in the results may pertain to the same methodology employed, which is GMM panel estimation technique.

In the same vein, Polat \& Payaslığlu (2015), in their study, examined the impact of real exchange rate level on FDI inflows to Turkey using monthly data for 2004-2014 period and the results showed that there is no significant effect of real exchange rate on FDI. The similar findings of the study compared to this study can be attributed to the fact that both studies examined inward FDI to developing countries. Hence, it can be concluded that the impact of exchange rate level may be insignificant for developing countries.

H2: There is a significant relationship between Exchange Rate Volatility and inward FDI flows into Egypt.

As shown in Table 5, the relative real exchange rate volatility has a significant positive impact on FDI inflow to Egypt at the one percent level, $(\beta=0.109, p=$ 0.022 ), and an increase in relative exchange rate volatility by 1 unit, increases inward FDI to Egypt by $\$ 0.109$ million, which means that as the exchange rate volatility of source countries increases relative to the Egyptian Pound, the amount of multinational activities rises. Cushman (1985) demonstrated that this is due to the fact that as the unpredictability of exchange rate fluctuations grows, investing in market-seeking FDI becomes a substitute for exports. This could be the case of source countries having high currency volatility relative to the Egyptian Pound; hence, source countries choose FDI over exporting to avoid international trade costs, and simply due to the fluctuated currency, the prices of the exported products from source countries to Egypt can be risky.

The positive effect of exchange rate volatility was also confirmed by Kimino et al. (2007) and Liu (2010). These studies corroborated the risk aversion theory, or the so called hysteresis approach adopted by Dixit and Pindyck (1994), which suggested that where there is a higher exchange rate volatility, the less will be the FDI inflows, accordingly, multinational firms choose to simply avoid the risk or choose to postpone the decision of investment until they can guarantee the rate of return from these investments. This theory is confirmed by the findings of this study as the investing company located in source countries experiencing high volatility of exchange rate tends to search for a host country where there is a lower exchange rate volatility to invest to guarantee the expected return from this investment. In other words, the findings of this study support the existence of a negative relationship between exchange rate volatility in host country and FDI inflows to Egypt, which also confirms the risk aversion argument. The similarity with the study of Liu (2010) may be attributed to GMM estimation technique as the same methodology is used in this study.

Furthermore, this research also supports the findings of the studies conducted by [Coleman \& Tettey (2008), Dal Bianco \& To Loan (2017)]. The same findings of a significant negative impact of exchange rate volatility on inward FDI compared to the study of Coleman \& Tettey may be pertained to the host countries in both studies, as the host country is Ghana, while the host country of this study is Egypt which are both considered developing countries. Similar findings with 
Dal Bianco \& To Loan may be attributed to the same method employed GARCH $(1,1)$ to measure the volatility of exchange rate and that the study examined inward FDI to Latin America which are considered developing countries as stated in World Economic Situation Prospects (2020).

H3: There is a significant relationship between market size of home country market and inward FDI flows into Egypt.

Source country GDP-used as a proxy for market size-impacts positively and significantly FDI inflows into Egypt $(\beta=7.56 \mathrm{e}-11, p=0.000)$ which implies that the third hypothesis is accepted. This hypothesis is interpreted by using the market size hypothesis which states that high real GDP of source countries means a large market size, hence, the larger the market size of source countries, the more inward FDI flows to Egypt. This is demonstrated by the larger the market size, the more likely there will be large firms that are capable and motivated to grow internationally and decide to invest in a host country. From the empirical perspective, the significant positive impact of market size is supported by many studies such as the ones conducted by Tallman (1988) and Grosse \& Trevino (1996).

Using the gravity model in which one of the main determinants of FDI is source country market size, which suggests that the larger the market size of the source country, the higher the inward FDI to a country. This study is consistent with the gravity model concerning the market size of source countries. Studies conducted that confirm the positive and significant impact of market size of the home country on inward FDI such as Barrell et al. (2017) and Jena \& Mishra (2018).

H4: There is a significant relationship between market size of host country and inward FDI flows into Egypt.

According to the results obtained from the research model analysis, Egypt market size impacts positively and significantly inward FDI flows into Egypt ( $\beta$ $=5.56 \mathrm{e}-10, p=0.000$ ) which means that the larger the market size of Egypt is, the more inward FDI is engaged.

This result is consistent with many studies that found the positive relationship between host country market size and FDI inflows to host country such as the one conducted by Majeed \& Ahmad (2009), Hoang \& Bui (2015), Barrell et al. (2017), and Beloucif et al. (2020). This finding is interpreted by highlighting the importance of a large market in order to use the resource efficiently as well as exploiting economies of scale. Hence, the larger the market, the higher the demand, the more the market have the capacity to absorb resources and finally the more foreign investors are encouraged to invest in this market. Furthermore, the market size variable in FDI gravity model leads to an explanation that source countries are motivated for horizontal FDI.

H5: There is a significant relationship between the geographic distance between the country of origin and inward FDI flows into Egypt.

As it can be depicted from Table 5 that there is a significant and negative relationship between geographic distance and inward FDI to Egypt ( $\beta=-0.0418, p$ 
$=0.000$ ), which means the longer the distance between the capital of source country and Cairo, the lower inward FDI into Egypt.

This is interpreted that geographic distance is explained through the transportation costs as well as communication between the source country and host country. Hence, it is considered as a key factor for efficiency-seeking investors. This study is congruent with the gravity model of FDI which states that geographic distance negatively affects FDI inflows, as well as many studies conducted by Grosse and Trevino (1996), Thomas and Grosse (2001), Miroslav (2009). In addition, Jena \& Mishra (2018) explained that the longer the distance between the host and home countries, the more difficult managing and supervising FDI in the host country; thus, lower FDI inflows to the host country as home countries are discouraged by the long distance.

H6: There is a significant relationship between existing bilateral trade between and inward FDI flows into Egypt.

According to the results obtained from the research model analysis, this hypothesis is accepted as the existing bilateral trade between each source country and Egypt has proved a positive and significant effect on inward FDI into Egypt $(\beta=0.030, p=0.000)$. Then, this positive coefficient is interpreted that bilateral trade which is the exports from the source countries into Egypt and imports into the source countries from Egypt is complement to FDI, which corroborates with the vertical FDI theory developed by Helpman (1984) that states that source countries are engaged in FDI as well as export to host countries concurrently and that both are not considered as substitutions. Thus, source countries may be engaged in vertical FDI and searching for a lower cost of production in a foreign country as well as exporting to foreign country, which leads to a conclusion that FDI is not used as export substitution in the case of Egypt, yet they are complementary. Hence, it can be stated that the type of FDI into Egypt is a vertical FDI according to this variable only.

This result is consistent with the studies conducted by Thomas \& Grosse (2001), Bevan \& Estrin (2004) and Kahouli \& Maktouf (2015). Similarly, this study corroborates with the study of Kahouli \& Omri (2017), in which the existing bilateral trade has a positive and significant impact on inward FDI using difference-GMM.

H7: There is a significant relationship between cost of borrowing and inward FDI flows into Egypt.

Regarding the cost of borrowing, it can be depicted from Table 5 that relative lending rate positively and significantly impacts inward FDI into Egypt at one per cent level $(\beta=0.7441, p=0.000)$, which means that the level of inward FDI to Egypt increases by 0.74 percent as the lending rate of source countries rises by one percent relative to those of Egypt.

This finding is explained as the firms located in source countries, where there is a high lending rate, are searching for a host country where a lower lending rate exists and decide to invest in this country with a lower cost of capital relative to the source country. These results are consistent with many studies such as the 
one conducted by Kimino et al. (2007) who found that the higher the lending rate in source countries compared to Japan as host country, the more inward FDI to Japan. Furthermore, Alon et al. (2012) found a modest evidence that host countries having more advantageous credit conditions is an incentive that encourages Chinese firms to invest overseas.

H8: There is a significant relationship between labor productivity and inward FDI flows into Egypt.

The impact of relative labor productivity on inward FDI to Egypt is significantly positive at 1 percent level $(\beta=11.189, p=0.000)$, and an increase in relative labor productivity, increases inward FDI to Egypt, which means that as labor productivity of source countries increases relative to the labor productivity in Egypt, inward FDI to Egypt increases.

The finding of this study is congruent with Holland \& Pain (1998), which examined the impact of labor productivity on FDI in CEECs and claimed that investors located in source countries were capable of dealing with a lower labor productivity through the transfer of resources from source county to host country. In addition, Cuong, Thu, \& Trang (2018) found mixed results and showed that labor productivity negatively affects inward FDI to ASEAN 10 which confirm the findings of this study that the lower the labor productivity the more inward FDI to host country.

According to the above discussion, the higher the relative labor productivity the more FDI inflows to the host country which means that source countries choose and continue to invest in host country where there is a lower labor productivity compared to source country, and that the latter is willing to transfer the know-how, the technology, and any resources needed. The differences in the obtained results may be attributed to the labor cost, as source countries may search for host countries where they have a lower wage rate relative to the source countries. In this case, source countries investing in Egypt might not need high skilled labor.

H9. There is a significant relationship between corruption and inward FDI flows into Egypt.

The relative corruption significantly and positively impacts inward FDI to Egypt $(\beta=4.638, p=0.000)$ which means that lower level of corruption in source countries relative to those of Egypt increases inward FDI to Egypt.

This finding is interpreted by the low level of corruption in source countries which makes the investor choose to invest in a foreign country where there is more corruption, thus, the foreign investor chooses to invest in Egypt looking for a host country where they bribe in order to quicken the procedures and not waste time. Therefore, firms are encouraged to conduct business in high-corrupted countries in order to have better opportunities and productivity.

Moreover, this study is consistent with the study conducted by Moustafa (2020) where the results showed the positive impact of corruption on FDI inflows to Egypt and demonstrated that investing in a corrupted environment may be advantageous to speed up the business process. Hence, foreign investors may 
be willing to bribe in order to cut down on their wait time and get their deal quickly. Corruption, when considered from a theoretical standpoint, could be viewed as a "grabbing hand". However, it is important to understand that these results should not be construed as a demonstration of support for corrupt regimes.

H10: There is a significant relationship between the cultural differences and inward FDI inflows into Egypt.

Cultural distance between source countries and Egypt is insignificant ( $\beta=$ 27.40587, $p=0.278$ ), by this, the last hypothesis of the research has been rejected. This result is consistent with the study conducted by Habib \& Zurawicki (2002) employing the Kogut and Singh formula for Hofstede four cultural dimensions and the results found the insignificant impact of cultural distance on FDI, then omitted this variable from their study. In addition, the study conducted by Roberts \& Almahmood (2009) examined the impact of cultural distance on FDI inflows into Saudi Arabia by source countries, and found the statistically insignificant impact of cultural distance. This can be interpreted by the concept of cultural differences between source countries and host country as it is not a significant determinant when the investor located in source country decide where to invest, there are other determinants that are more significant in their decision than cultural distance. Similar findings with the study of Roberts \& Almahmood may be attributed to two reasons; firstly, the fact that Saudi Arabia and Egypt are both developing countries where the foreign investor does not give emphasis to cultural distance. Secondly, it may be pertained to the gravity model as both studies employed this model for FDI.

Table 6 provides a summary of the main results obtained as response to the research hypotheses.

\section{Recommendations}

Since FDI has a significant impact on the global economy, knowing its drivers is critical for the host country to promote and implement FDI-attractive programs. The findings of the current study provide policymakers with guidance and new insights for making Egypt more attractive to investors. Therefore, policymakers should make a concerted effort to what attracts more FDI in Egypt. Hence, setting policies that engage more inward FDI and shedding light on examining multidimensional determinants, volatility of exchange rate is considered as a risk, and source countries are searching for a host country where there is lower currency volatility. As a result, it is necessary to implement suitable economic policies in order to minimize exchange rate volatility. Monetary policy has to be adopted by government so the exchange rate is maintained stable. Further, policymakers can concentrate on GDP because it has shown a positive and significant impact on inward FDI, thus plans to increase GDP should be developed. Concerning the significant impact of bilateral trade on inward FDI, a key economic policy for developing countries to increase the bilateral trade is the liberalization of trade and the removal of trade barriers. 
Table 6. Summary of research hypotheses results.

\begin{tabular}{|c|c|}
\hline Hypotheses & Results \\
\hline $\begin{array}{l}\text { H1: There is a significant relationship between source countries } \\
\text { with an appreciating currency and inward FDI flows into Egypt. }\end{array}$ & Rejected \\
\hline $\begin{array}{l}\text { H2: There is a significant relationship between Exchange Rate } \\
\text { Volatility and inward FDI flows into Egypt. }\end{array}$ & Accepted \\
\hline $\begin{array}{l}\text { H3: There is a significant relationship between market size of } \\
\text { home country market and inward FDI flows into Egypt. }\end{array}$ & Accepted \\
\hline $\begin{array}{l}\text { H4: There is a significant relationship between market size of } \\
\text { host country and inward FDI flows into Egypt. }\end{array}$ & Accepted \\
\hline $\begin{array}{l}\text { H5: There is a significant relationship between the geographic } \\
\text { distance between the country of origin and inward FDI flows } \\
\text { into Egypt. }\end{array}$ & Accepted \\
\hline $\begin{array}{l}\text { H6: There is a significant relationship between existing bilateral } \\
\text { trade between and inward FDI flows into Egypt. }\end{array}$ & Accepted \\
\hline $\begin{array}{l}\text { H7: There is a significant relationship between cost of borrowing } \\
\text { and inward FDI flows into Egypt. }\end{array}$ & Accepted \\
\hline $\begin{array}{l}\text { H8: There is a significant relationship between labor productivity } \\
\text { and inward FDI flows into Egypt. }\end{array}$ & Accepted \\
\hline $\begin{array}{l}\text { H9. There is a significant relationship between corruption and } \\
\text { inward FDI flows into Egypt. }\end{array}$ & Accepted \\
\hline $\begin{array}{l}\text { H10. There is a significant relationship between the cultural } \\
\text { differences and inward FDI inflows into Egypt. }\end{array}$ & Rejected \\
\hline
\end{tabular}

Another point that is of great importance is the lending rate on private loans. Investors located in source countries who are in need for capital will absolutely compare lending rate of Egypt to that in the home country, as investors seek a lower cost of capital. On the practical side, government can identify what may represent a challenge or a risk for foreign investors that might discourage them from investing in the host country. This study has provided insights for government and policymakers that assist them in setting more effective policies and incentives according to the findings of the study to attract more inward FDI.

\section{Conclusion}

In this research, the impact of relative exchange rate volatility and other multidimensional determinants on inward FDI to Egypt by country of origin have been investigated. This has been achieved using data collected for Egypt and 42 source countries over the period 2005-2019 while employing difference GMM estimation technique. Results have revealed that the impact of relative exchange rate volatility will have only a positive effect on inward FDI if the currency volatility of the source country is higher than that of the host country. In addition, the impact of market size of source countries and host country has a positive impact on inward FDI if the host country market is large enough with high de- 
mands. In addition, the more existing bilateral trade between the source countries and host country, the more inward FDI to host country. Furthermore, relative cost of borrowing positively impacts inward FDI to host country; this will hold if the cost of borrowing in the source country is higher than those in the host country. Additionally, the higher the relative labor productivity, the more inward FDI into host country. As of the relative corruption between source and host country, the lower corrupted source country relative to host country, the more inward FDI. Further, the larger the geographic distance between the capital of source and host countries, the lower inward FDI to the host country. Results have also revealed the insignificance of relative real exchange rate as well as the cultural distance on inward FDI to Egypt. This research may provide some insights and stimulate some thoughts regarding the policies that can be implemented by policymakers to enhance inward FDI to Egypt as the findings of this research will provide guidelines for policymakers to adopt more effective exchange rate policies and other incentives to engage more FDI inflows. Since the unavailability of multidimensional data about Egypt and 42 sampled source countries in only one secondary source, they were gathered from various sources. Additionally, there is unavailability of a complete data for one of the most important determinant of FDI such as labor wage for some countries in the selected sample which may result in the existence of some implications that may not help for developing a better understanding of what attracts more inward FDI. Finally, the lack of diversity in the host country in the current study is another limitation of the current study. Therefore, it is recommended for further studies to investigate other host countries in which different source countries are investing. Moreover, this research also seeks to encourage researchers to conduct more similar studies in this area as well as employing the gravity model which will eventually result in better understanding of FDI determinants specifically the relative labor productivity concept and its impact on inward FDI.

\section{Conflicts of Interest}

The authors declare no conflicts of interest regarding the publication of this paper.

\section{References}

Abdullah, H., Bakar, N., \& Hassan, S. (2006). Analysis of FDI Inflows to China from Selected ASEAN Countries: A Panel Cointegration Approach. Journal of Economic Cooperation and Development, 35, 1-28.

Abel, A. B. (1983). Optimal Investment under Uncertainty. The American Economic Review, 73, 228-233.

Aizenman, J. (1992). Exchange Rate Flexibility, Volatility, and Domestic and Foreign Direct Investment. International Monetary Fund Staff Papers, 39, 890-922. https://doi.org/10.2307/3867425

Ajami, R. A., \& Barniv, R. (1984). Utilizing Economic Indicators in Explaining Foreign Direct Investment in the U.S. Management International Review, 24, 16-26. 
Aliber (1970). A Theory of Direct Investment. In C. P. Kindleberger (Ed.), The International Corporation, Assymposium Combrite MA (pp. 17-34). MIT Press.

Alon, I., Molodtsova, T., \& Zhang, J. (2012). Macroeconomic Prospects for China's Outward FDI, 4, 16-40. https://doi.org/10.1080/19186444.2012.11658324

Arellano, M., \& Bond, S. (1991). Some Tests of Specification for Panel Data: Monte Carlo Evidence and an Application to Employment Equations. Review of Economic Studies, 58, 277-297. https://doi.org/10.2307/2297968

Arpan, J. S., Flowers, E. B., \& Ricks, D. A. (1981). Foreign Direct Investment in the United States: The State of Knowledge in Research. Journal of International Business Studies, 12, 137-154. https://doi.org/10.1057/palgrave.jibs.8490575

Asiamah, M., Ofori, D., \& Afful, J. (2019). Analysis of the Determinants of Foreign Direct Investment in Ghana. Journal of Asian Business and Economic Studies, 26, 56-75. https://doi.org/10.1108/JABES-08-2018-0057

Asmah, E. E., \& Andoh, F. K. (2013). Exchange Rate Volatility and Foreign Direct Investment in Sub-Saharan Africa. Journal for the Advancement of Developing Economies, 2, 21.

Azhar, A., Ullah, N., \& Malik, Q. A. (2015). Effect of Exchange Rate Volatility on Foreign Direct Investment in Saarc Countries. Middle-East Journal of Scientific Research, 23, 350-356.

Aziz, J., \& Caramazza, F. (1998). Fixed or Flexible? Getting the Exchange Rate Right in the 1990s (p. 25). International Monetary Fund, Economic Issues.

https://doi.org/10.5089/9781455220038.051

Balaban, S., Živkov, D., \& Milenković, I. (2019). Impact of an Unexplained Component of Real Exchange Rate Volatility on FDI: Evidence from Transition Countries. Economic Systems, 43, 1-14. https://doi.org/10.1016/j.ecosys.2019.100719

Barrell, R., Gottschalk, S., \& Hall, S. (2003). Foreign Direct Investment and Exchange Rate Uncertainty in Imperfectly Competitive Industries. NIESR Discussion Paper 220.

Barrell, R., Nahhas, A., \& Hunter, J. (2017). Exchange Rate and Bilateral FDI: Gravity Models of Bilateral FDI in High Income Economies. Working Paper 17-07, Brunel Univesity.

Bellak, C., Leibrecht, M., \& Riedl, A. (2008). Labour Costs and FDI Flows into Central and Eastern European Countries: A Survey of the Literature and Empirical Evidence. Structural Change and Economics Synamics, 19, 17-37. https://doi.org/10.1016/j.strueco.2007.03.001

Beloucif, A., Islam, M. S., \& Boukhobza, T. (2020). An Empirical Study of FDI Determinants: A Panel Data Analysis of South and South-East Asia. In Proceedings of the 2020 British Academy of Management Annual Conference (pp. 1-20). University of the West of Scotland.

Bénassy-Quéré, A., Fontagné, L., \& Lahrèche-Révil, A. (2001). Exchange-Rate Strategies in the Competition for Attracting Foreign Direct Investment. Journal of the Japanese and International Economies, 15, 178-198. https://doi.org/10.1006/jjie.2001.0472

Bevan, A. A., \& Estrin, S. (2004). The Determinants of Foreign Direct Investment into European Transition Economies. Journal of Comparative Economics, 32, 775-787. https://doi.org/10.1016/j.jce.2004.08.006

Bollerslev, T. (1986). Generalized Autoregressive Conditional Heteroskedasticity. Journal of Econometrics, 31, 307-327. https://doi.org/10.1016/0304-4076(86)90063-1

Bouoiyour, J., \& Rey, S. (2005). Exchange Rate Regime, Real Exchange Rate, Trade Flows and Foreign Direct Investments: The Case of Morocco. African Development Review, 


\section{7, 302-334. https://doi.org/10.1111/j.1017-6772.2005.00117.x}

Brooks, C. (2008). Introductory Econometrics for Finance (2nd ed.). Cambridge University Press. https://doi.org/10.1017/CBO9780511841644

Brzozowski, M. (2006). Exchange Rate Variability and Foreign Direct Investment: Consequences of EMU Enlargement. Eastern European Economics, 44, 5-24. https://doi.org/10.2753/EEE0012-8755440101

Camba-Mendez, G., Durré, A., \& Mongelli, F. P. (2016). Bank Interest Rate Setting in the Euro Area during the Great Recession (p. 36). European Central Bank Working Paper No. 1965. https://doi.org/10.2139/ssrn.2840641

Campa, J. M. (1993). Entry by Foreign Firms in the United States under Exchange Rate Uncertainty. The Review of Economics and Statistics, 75, 614-622. https://doi.org/10.2307/2110014

Caves, R. E. (1971). International Corporations: The Industrial Economics of Foreign Investment. Economica, 38, 1-27. https://doi.org/10.2307/2551748

Chaudhary, G. M., Shah, S. Z., \& Bagram, M. M. (2012). Do Exchange Rate Volatility Effects Foreign Direct Investment? Evidence from Selected Asian Economies. Journal of Basic and Applied Scientific Research, 2, 3670-3681.

Chowdhury, A., \& Wheeler, M. (2008). Does Real Exchange Rate Volatility Affect Foreign Direct Investment? Evidence from Four Developed Countries. The International Trade Journal, 22, 218-245. https://doi.org/10.1080/08853900801970601

Coleman, A. K., \& Tettey, K. F. (2008). Effect of Exchange Rate Volatility on Foreign Direct Investment in Sub-Saharan Africa The case of Ghana. The Journal of Risk Finance, 9, 52-70. https://doi.org/10.1108/15265940810842410

Culem, C. G. (1988). The Locational Determinants of Direct Investments among Industrialized Countries. European Economic Review, 32, 885-904.

https://doi.org/10.1016/0014-2921(88)90051-7

Cuong, H. C., Thu, N. V., \& Trang, T. T. (2018). Determinants of Foreign Direct Investment Inflows into ASEAN Countries: A GLS Estimation Technique Approach. Journal of International Economics and Management, 101, 1-21.

Cushman, D. O. (1985). Real Exchange Rate Risk Expectation and Level of Direct Investment. Review of Economic and Statistics, 67, 297-308.

https://doi.org/10.2307/1924729

Cushman, D. O. (1988). Exchange-Rate Uncertainty and Foreign Direct Investment in the United States. Weltwirtschaftliches Archiv, 124, 322-336.

https://doi.org/10.1007/BF02706782

Dal Bianco, S., \& To Loan, N. C. (2017). FDI Inflows, Price and Exchange Rate Volatility: New Empirical Evidence from Latin America. International Journal of Financial Studies, 5, 1-17. https://doi.org/10.3390/ijfs5010006

Darby, J., Hallett, A. H., Ireland, J., \& Piscitelli, L. (1999). The Impact of Exchange Rate Uncertainty on the Level of Investment. The Economic Journal, 109, 55-67. https://doi.org/10.1111/1468-0297.00416

Dauti, B. (2015). Determinants of Foreign Direct Investment in Transition Economies, with Special Reference to Macedonia. Evidence from Gravity Model. South East European Journal of Economics and Business, 10, 7-28.

https://doi.org/10.1515/jeb-2015-0007

De Vita, G., \& Abbott, A. (2008). Do Exchange Rates Have Any Impact upon UK Inward Foreign Direct Investment? Applied Economics, 39, 2553-2564.

https://doi.org/10.1080/00036840600749748 
Del BO, C. (2009). Foreign Direct Investment, Exchange Rate Volatility and Political Risk.

Dhakal, D., Nag, R., Pradhan, G., \& Upadhyaya, K. P. (2010). Exchange Rate Volatility and Foreign Direct Investment: Evidence from East Asian Countries. International Business \& Economics Research Journal, 9, 121-128. https://doi.org/10.19030/iber.v9i7.603

Dixit, A., \& Pindyck, R. (1994). Investment under Uncertainty. Princeton U. Press. https://doi.org/10.1515/9781400830176

Dunning, H. (1977). Trade, Location of Economic Activity and the MNE: A Search for an Eclectic Approach. The International Allocation of Economic Activity. https://doi.org/10.1007/978-1-349-03196-2_38

Dunning, J. (1979). Explaining Changing Patterns of International Production: In Defence of the Eclectic Theory. Oxford Bulletin of Economics and Statistics, 41, 269-295. https://doi.org/10.1111/j.1468-0084.1979.mp41004003.x

Dunning, J. (1980). Towards an Eclectic Theory of International Production: Some Empirical Tests. Journal of International Business Studies, 11, 9-31. https://doi.org/10.1057/palgrave.jibs.8490593

Dunning, J. (1988). The Eclectic Paradigm of International Production: A Restatement and Some Possible Extensions. Journal of International Business Studies, 19, 1-31. https://doi.org/10.1057/palgrave.jibs.8490372

Dunning, J. (1993). Multinational Enterprises and the Global Economy. Addison-Wesley Publication Company.

Eaton, J., \& Tamura, A. (1994). Bilateralism and Regionalism in Japanese and U.S Trade and Direct Investment Patterns. Journal of the Japanese and International Economies, 8, 478-510. https://doi.org/10.1006/jjie.1994.1025

Egger, P., \& Winner, H. (2006). How Corruption Influences Foreign Direct Investment: A Panel Data Study. Economic Development and Cultural Change, 54, 459-486. https://doi.org/10.1086/497010

Ellahi, N. (2011). Exchange Rate Volatility and Foreign Direct Investment (FDI) Behavior in Pakistan: A Time Series Analysis with Auto Regressive Distributed Lag (ARDL) Application. African Journal of Business Management, 5, 11656-11661. https://doi.org/10.5897/AJBM11.1676

ElShazly, M. (2020). Determinants of Foreign Direct Investment in Developing Countries: 1990-2017. Master's Thesis, The American University.

Froot, K., \& Stein, J. (1991). Exchange Rates and Foreign Direct Investment: An Imperfect Capital Markets Approach. Quarterly Journal of Economics, 427, 1191-1217. https://doi.org/10.2307/2937961

Fuentelsaz, L., Garrido, E., \& Maicas, J. P. (2020). The Effect of Informal and Formal Institutions on Foreign Market Entry Selection and Performance. Journal of International Management, 26, Article ID: 100735. https://doi.org/10.1016/j.intman.2020.100735

Gagne, O. (2018). Cultural Distance and FDI: China Africa Perspective. Open Journal of Business and Management, 6, 382-399. https://doi.org/10.4236/ojbm.2018.62028

Gao, T. (2005). Foreign Direct Investment in China: How Big Are the Roles of Culture and Geography? Pacific Economic Review, 10, 153-166. https://doi.org/10.1111/j.1468-0106.2005.00265_10_2.x

Goldberg, L. S., \& Kolstad, C. D. (1995). Foreign Direct Investment, Exchange Rate Variability and Demand Uncertainty. International Economic Review, 36, 855-873.

https://doi.org/10.2307/2527262 
Grosse, R., \& Trevino, L. J. (1996). Foreign Direct Investment in the United States: An Analysis by Country of Origin. Journal of International Business Studies, 27, 139-155. https://doi.org/10.1057/palgrave.jibs.8490129

Habib, M., \& Zurawicki, L. (2002). Corruption and Foreign Direct Investment. Journal of International Business Studies, 33, 291-307.

https://doi.org/10.1057/palgrave.jibs.8491017

Hafeez, A. (2016). The Impact of Productivity on Foreign Direct Investment in Pakistan: A Structural VAR Analysis. The Pakistan Development Review, 105-119. http://www.jstor.org/stable/44986478

Hanh, P. T. (2020). Determinants of FDI into China and Vietnam: A Comparative Study. Korea and the World Economy, 21, 35-73. https://doi.org/10.46665/kwe.2020.04.21.1.35

Head, K., \& Mayer, T. (2014). Gravity Equations: Workhorse, Toolkit, and Cookbook. In Handbook of International Economics (pp. 131-195). Elsevier. https://doi.org/10.1016/B978-0-444-54314-1.00003-3

Helpman, E. (1984). A Simple Theory of International Trade with Multinational Corporations. The Journal of Political Economy, 92, 451-471. https://doi.org/10.1086/261236

Hoang, H. H., \& Bui, D. H. (2015). Determinants of Foreign Direct Investment in ASEAN: A Panel Approach. Management Science Letters, 5, 213-222. https://doi.org/10.5267/j.msl.2014.12.015

Hofstede, G. (1980). Culture's Consequences: International Differences in Work-Related Values. Beverly Hills.

Holland, D., \& Pain, N. (1998). The Diffusion of Innovations in Central and Eastern Europe: A Study of the Determinants and Impact of Foreign Direct Investment. NIESR Discussion Paper No. 137. London: National Institute for Economic and Social Research.

Imansyah, N. (2017). The Impact of ASEAN Economic Integration on Indonesia Foreign Direct Investment: A Panel Gravity Model Approach. Journal of Distribution Science, 14, 33-38. https://doi.org/10.15722/jds.14.4.201604.33

Ismail, N. W. (2009). The Determinant of Foreign Direct Investment in ASEAN: A Semi-Gravity Approach. Transition Studies Review, 16, 710-722.

https://doi.org/10.1007/s11300-009-0103-0

Jeanneret, A. (2007). Foreign Direct Investment and Exchange Rate Volatility: A Non-Linear Story. Working Paper Series.

Jena, P. K., \& Mishra, B. R. (2018). Bilateral FDI Flows in Four Major Asian Economies: A Gravity Model Analysis. Journal of Economic Studies, 46, 71-89. https://doi.org/10.1108/JES-07-2017-0169

Kahouli, B., \& Maktouf, S. (2015). The Determinants of FDI and the Impact of the Economic Crisis on the Implementation of RTAs: A Static and Dynamic Gravity Model. International Business Review, 24, 518-529. https://doi.org/10.1016/j.ibusrev.2014.10.009

Kahouli, B., \& Omri, A. (2017). Foreign Direct Investment, Foreign Trade and Environment: New Evidence from Simultaneous-Equation System of Gravity Models. Research in International Business and Finance, 42, 353-364.

https://doi.org/10.1016/j.ribaf.2017.07.161

Kayam, S., \& Hisarciklilar, M. (2009). Determinants of Turkish FDI Abroad. MPRA Paper, University Library of Munich.

Kenneth, M. K., Muniu, J., \& Kosgei, M. (2017). Short and Long Run Effects on Exchange 
Rate Volatility on Foreign Direct Investment in Kenya. International Journal of Economics, Commerce and Management, 5, 386-399.

Khan, U. U., Sultan, F., \& Rehman, Z. U. (2017). An Analysis of Exchange Rate Volatility and FDI Inflow in Pakistan; Using ARDL Bound Testing Technique (1981-2015). International Journal of Applied Economic Studies, 5, 1-9.

Kimino, S. S., Saal, D., \& Driffield, N. (2007). Macro Determinants of FDI Inflows to Japan: An Analysis of Source Country Characteristics. The World Economy, 30, 446-469. https://doi.org/10.1111/j.1467-9701.2007.01001.x

Korzeb, Z. (2021). Cultural Differences as a Reason for Failure of Investment Projects in the Polish Banking Sector. WSEAS Transactions on Business and Economics, 18, 152-162. https://doi.org/10.37394/23207.2021.18.16

Lemi, A., \& Asefa, S. (2001). Foreign Direct Investment and Uncertainty: Implications for Ethiopia. In International Conference on African Development Archives (pp. 1-21). Center for African Development Policy Research, Western Michigan University.

Liu, W. H. (2010). Determinants of FDI Inflows to China: An Empirical Analysis of Source Country Characteristics. In Taipei International Conference on Growth, Trade and Dynamics (1-18).

Liu, X., Song, H., Wei, Y., \& Romilly, P. (1997). Country Characteristics and Foreign Direct Investment in China: A Panel Data Analysis. Weltwirtschaftliches Archiv, 133, 313-329. https://doi.org/10.1007/BF02707466

Loree, D. W., \& Guisinger, S. E. (1995). Policy and Non-Policy Determinants of U.S Equity Foreign Direct Investment. Journal of International Business Studies, 26, 281-299. https://doi.org/10.1057/palgrave.jibs.8490174

Lui, F. T. (1985). An Equilibrium Queuing Model of Bribery. Journal of Political Economy, 93, 760-781. https://doi.org/10.1086/261329

Majeed, M. T., \& Ahmad, E. (2009). An Analysis of Host Country Characteristics That Determine FDI in Developing Countries: Recent Panel Data Evidence. The Labor Journal of Economics, 14, 71-96. https://doi.org/10.35536/lje.2009.v14.i2.a3

Miroslav, M. (2009). Determinants of Foreign Direct Investment in Central and Southeastern Europe: New Empirical Tests. Oxford Journal, 8, 133-149.

Moustafa, E. (2020). Foreign Direct Investment and Corruption in Egypt: A Cointegration Analysis. Economic Research Forum (1408).

Osinubi, T. S., \& Amaghionyeodiwe, L. A. (2009). Foreign Direct Investment and Exchange Rate Volatility in Nigeria. International Journal of Applied Econometrics and Quantitative Studies, 6, 83-116.

Pan, Y. (2003). The Inflow of Foreign Direct Investment to China: The Impact of Country-Specific Factors. Journal of Business Research, 56, 829-833. https://doi.org/10.1016/S0148-2963(02)00470-8

Parajuli, S., \& Kennedy, P. (2010). The Exchange Rate and Inward Foreign Direct Investment in Mexico. Orlando: Southern Agricultural Economics Association.

Polat, B., \& Payaslıoğlu, C. (2015). Exchange Rate Uncertainty and FDI Inflows: The Case of Turkey. Asia-Pacific Journal of Accounting \& Economic, 23, 112-129. https://doi.org/10.1080/16081625.2015.1032312

Ray, E. J. (1989). The Determinants of Foreign Direct Investment in the United States, 1979-85. In Trade Policies for International Competitiveness (pp. 53-77). University of Chicago Press.

Roberts, B. M., \& Almahmood, A. (2009). Source Country Characteristics and the Inflow of Foreign Direct Investment into Saudi Arabia. The World Economy, 32, 1730-1756. 
https://doi.org/10.1111/j.1467-9701.2009.01205.x

Rodríguez, X. A., \& Pallas, J. (2008). Determinants of Foreign Direct Investment in Spain. Applied Economics, 40, 2443-2450. https://doi.org/10.1080/00036840701367606

Root, F. R., \& Ahmed, A. A. (1979). Empirical Determinants of Manufacturing Direct Foreign Investment in Developing Countries. Economic Development and Cultural Change, 27, 751-767. https://doi.org/10.1086/451139

Stone, S. F., \& Jeon, B. N. (2000). Foreign Direct Investment and Trade in the Asia-Pacific Region: Complementarity, Distance and Regional Economic Integration. Journal of Economic Integration, 15, 460-485. https://doi.org/10.11130/jei.2000.15.3.460

Sung, H., \& Lapan, H. (2000). Strategic Foreign Direct Investment and Exchange-Rate Uncertainty. International Economic Review, 41, 411-423. https://doi.org/10.1111/1468-2354.00069

Tallman, S. B. (1988). Home Country Political Risk and Foreign Direct Investment in the United States. Journal of International Business Studies, 19, 219-234. https://doi.org/10.1057/palgrave.jibs.8490856

Taylor, M. P., \& Sarno, L. (1998). The Behavior of Real Exchange Rates during the Post-Bretton Woods Period. Journal of International Economics, 46, 281-312. https://doi.org/10.1016/S0022-1996(97)00054-8

Thomas, E. D., \& Grosse, R. (2001). Country-of-Origin Determinanys of Foreign Direct Investment in an Emerging Market: The Case of Mexico. Journal of International Management, 7, 59-79. https://doi.org/10.1016/S1075-4253(00)00040-5

Ullah, S., Haider, S. Z., \& Parvez, A. (2012). Impact of Exchange Rate Volatility on Foreign Direct Investment: A Case Study of Pakistan. Pakistan Economic and Social Review, 50, 121-138.

UNCTAD (2006). World Investment Report.

UNCTAD (2020). World Investment Report.

World Economic Situation Prospects (2020). New York: United Nations.

Zhao, H. (2003). Country Factor Differentials as Determinants of FDI Flow to China. Thunderbird International Business Review, 45, 149-169.

https://doi.org/10.1002/tie.10067 